\title{
Recent Discoveries in Iberia and the Application of Post-Colonial Concepts: The Modern Making of a State, Tartessos ${ }^{1}$
}

\author{
By Eleftheria Pappa*
}

\begin{abstract}
The present paper offers a review of the current state of research on the protohistory of the southern Iberian peninsula, dealing specifically with the period of colonization in the first half of the 1st millennium BCE. It takes as a point of departure a synthetic picture presented in a recent publication that aims to diffuse knowledge on the subject to readerships outside this specific field. In doing so, however, it creates the precedent for the diffusion of a rather partial review of the evidence that presents contemporary interpretations that have not been met with a consensus, which fact remains unacknowledged. Here, the aim is to present a critical discussion of trends in the state of the art in this field of studies, highlighting problematic areas and giving some suggestions as to future lines of research. It concerns a major episode in the proto-history of the Mediterranean, in a period when writing spreads in Europe and local cultures across the Mediterranean are profoundly transformed through colonization.
\end{abstract}

\section{Introduction}

Spectacular archaeological discoveries in southern Iberia have continued apace in recent years, expanding our knowledge of the prehistoric and protohistoric periods associated with the so-called Tartessic culture. Given that this region was colonized by the Phoenicians (an umbrella term that includes other Near Easterners), the Iberian peninsula became embedded in cross-cultural developments taking place elsewhere in the Mediterranean, from Cyprus to Morocco. The recent scholarly interest in the Phoenicians has furthered research in Iberia itself, with the fine-tuning of typologies and the better understanding of cross-Mediterranean chronologies from excavations in Lebanon, Sardinia, Sicily, Tunisia, Morocco and elsewhere. New methods, such as radiocarbon dating, have entered the scene, complementing traditional archaeological approaches to dating. This is significant, as for modern historical reasons, Iberian archaeology followed a different trajectory than the eastern Mediterranean regions of the "classical world". The peninsula remained cut-off from the 18th century "Grand Tour explorations" and its archaeological record less known outside the country, a trend that continued in subsequent centuries.

This is where a new publication comes in, intended to diffuse a summary of the latest discoveries. It does so with the intention of applying new postcolonial concepts developed mainly within anthropology, albeit without avoiding methodological problems. Entitled Tartessos and the Phoenicians in

\footnotetext{
"Post-doctoral researcher, University of Sao Paulo, Brazil.

1. Review Article on Tartessos and the Phoenicians in Iberia, by S. Celestino Pérez \& C. López Ruiz, 2016, Oxford University Press.
} 
Iberia, the volume aims to present to a non-Spanish speaking readership recent archaeological discoveries in a "synthetic nature", avoiding "the technical details of the specialized archaeological publications aiming for a thorough but quicker overview of the material evidence" (iv). ${ }^{2}$ It focuses on Tartessos, a term known from archaic Greek sources, which in current archaeological terminology is associated with the early $1^{\text {st }}$ millennium BCE southern Iberia, centred in Andalousia and neighbouring regions. Authored by Sebastian Celestino Pérez, active in fieldwork in Spain and with a prodigious research output, $^{3}$ and Carolina López Ruiz, a classicist with an interest in the cultures of the ancient Near East, it combines archaeological and historical/philological evidence. Reading the monograph implicitly raises questions on the extent to which concepts from post-colonial theory can be applied to prehistoric archaeological evidence, and the risks of reifying ancient historiographical terms in a historical reality through the recruitment of archaeological finds.

\section{Reviewing the Synthesis of Current Knowledge Presented}

The monograph is composed of eight chapters, and an epilogue. The first four, written by López Ruiz, deal with the (mostly Spanish) history of research into Tartessos and the Greco-Roman literary sources. The last four, written by Celestino Pérez, address the archaeological evidence.

The Preface on why Tartessos matters, thus necessitating this monograph, emphasizes the dearth of related publications in English (iv). Some may view this as a rather damning evaluation of research done on the proto-history of southern Iberia in other languages, as it ignores older works, ${ }^{4}$ or more recent scholarship $^{5}$ whose topics overlap with those of this book. This evaluation is partly explained conceptually by the consideration implicit in the authors' treatment of Tartessos as a descrete entity, a "unit" detachable from the Iberian proto-history, which thus would explain the supposed dearth of publications on it outside Spain. This is discussed further below.

Chapter 1 begins with a historiographical account of the philological/historical and archaeological research on Tartessos in Spain. There is a section on the problems of defining and identifying ethnicity in the colonial worlds of ancient Iberia based on the archaeological evidence (22-23).

2. S. Celestino Pérez and C. López Ruiz, Tartessos and the Phoenicians in Iberia (Oxford: Oxford University Press, 2016).

3. Most recently: S. Celestino Pérez and E. Rodríguez González, (eds), Territorios Comparados: Los valles del Guadalquivir, el Guadiana y el Tajo en Época Tartésica, Anejos de Archivo Español de Arqueologia LXXX (Mérida: Consejo Superior de Investigaciones Científicas, 2017).

4. R. Harrison, R. Spain at the Dawn of History: Iberians, Phoenicians and Greeks (London: Thames and Hudson, 1988).

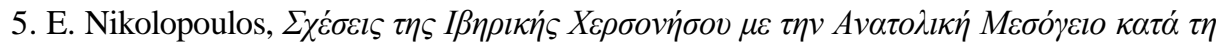

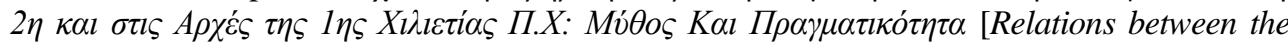
Iberian Peninsula and the Eastern Mediterranean in the 2nd and the beginning of 1 st millennium BC: Myth and Reality], Ph.D. Dissertation, National and Kapodistrian University of Athens, 2009. 
Chapter 2 deals with the Greek sources on Tartessos, beginning with $7^{\text {th }} \mathrm{c}$. BCE Ionian lyric poets, such as the earliest reference to Tartessos by the lyric poet Anacreon of Teos. The chapter offers a detailed account that is missing from other available publications on the topic, where Greek literary texts referring to Tartessos or to the western Mediterranean are mentioned en passante, without receiving a proper treatment of their own. Nonetheless, the problematic literary account of the famed journey of a certain Pytheas, from the Greek colony of Massalia (France) to an icy Thoule (modernly identified with places ranging from Scotland to Iceland) is curiously hailed as the "first notice we have of a renewed Greek activity in the Atlantic after a fifth century apparent gap" (49). The fragment on Pytheas, even if it was indeed based on some journey to northern Europe, cannot sustain the claim of Greek activity. Knowledge of the farthest regions of the Atlantic must have remained occasional and fragmented well into Roman times.

Chapter 3 discusses Roman-period Greek and Latin texts on Tartessos and its semantic heirs (e.g. Turdetania) through to the Augustan period. Tartessos in these texts emerges as the projection of an ancient prestigious culture. A critical discussion on semantics concludes that some of the termonological confusion derives from historiographers transliterating ethnonyms in Greek to Latin and the opposite without translating them. This resulted in multiple variations for the same ethnonym (e.g. Tourdetanoi/Turdetani). Dual toponyms (Tartessos/Baetis, Hispania/Iberia) are explained in the context of introduced Roman administrative terminology (58).

Chapter 4 deals with the cosmological conception of the "Far West" in Greek mythology (the Herakles' related myths of the Geryon's monsters and Gardens of Hesperidai) and eschatology (Isles of the Blessed). Various afterlife cosmologies from the Near East and Egypt to Greece are associated with the West, as the place where the sun sets. Early Greek mythological narratives situate the Hesperaidai by the Ocean in the western end of the world, without clearly referencing Iberia or Tartessos. The earliest documented association of Tartessos with the myth of Geryon is a $7^{\text {th }} / 6^{\text {th }} \mathrm{c}$. BCE lyric fragment by the Siceliot Greek Stecihorus (known through $3^{\text {rd }}$ c. BCE Strabo's writings). It is unclear from the analysis if the association between the Ocean in the "Far West" and Herakles/Melqart proceeded from 850-600 BCE Phoenician and Greek travellers' stories or whether they were a later "euphemeristic-style" development of the classical period. Potentially, the setting of some Greek myths (vaguely) in the West, understood as a cardinal point and afterlife abode at least from the classical period onwards - when geographical knowledge had improved - could have led to these mythical narratives being geographically associated with Iberia. Thus the Pillars of Herakles were identified with the Straits of Gibraltar (e.g. in Euripides' The Madness of Herakles). Continuing, the chapter offers a convincing case for identifying Tartessos with biblical Tarshish on the basis of historical, archaeological and importantly, linguistic grounds, furnishing the most persuasive treatment of this long-standing debate (113-114). While Chapter 4 is well-argued overall, its section on "final thoughts" is entirely out of kilter with the analysis previously presented, ending with a stunning conclusion: despite the extremely fragmented corpus of data it 
is asserted that "we can glimpse a realm with fairly well defined geographical and cultural contours, even if its precise ethnic and political composition and evolution remains a mystery" (124).

With Chapter 5 begins the archaeological, second part of the book. It introduces the application of post-colonial concepts as used in Mediterranean archaeology, defines terms used in the book ("Orientalizing", "Phoenicians"), and summarizes the evidence for Phoenician and Greek Mediterranean networks, as well as for pre-colonial contacts in Iberia. The first section on the theoretical approaches to colonization (125-129) raises questions. The authors talk of Phoenician colonization in several regions (from Cyprus to Portugal) (142), claiming that in the early $1^{\text {st }}$ millennium BCE Iberia "very little of that world resembles modern colonialism, which is premised on the systematic exploitation, domination and expansion of the colonial power" (127). In fact, one could claim that southern Iberia at this time presents a textbook-case of ancient colonialism. By juxtaposition with colonization, it is the weaker term regarding (hegemonic) power asymmetries.

Additionally, avoiding to use the words culture and ethnicity, as if they embodied a concept that is an inherently bad thing that needs to be avoided at all costs (lest it lend itself to nefarious purposes) results in confused statements, e.g. "We need to understand these Phoenicians and Greeks (at this stage at least) not as ethnically or culturally homogeneous, let alone politically unified, but rather as linked through common language (with dialectal variants) and a set of shared traditions, and practices, especially religious, that set them apart from others" (131). Here the authors are hopelessly trying to speak of cultural identities while at the same time claiming that they are precisely not doing that, as if so as to appease the most superficial of post-colonial narratives where words per se are demonized. This troubled understanding of the essence of post-colonial theory culminates with calling the settlement of Pithekoussai "a nice example of Greek and Phoenician early colonization" (142), although the only cogent attestation for Phoenicians on this trading post amounts to graffiti at a time during a period in which we have several lines of evidence documenting that Greeks and Phoenicians avoided settling one near the other in their colonial forays in the Mediterranean, as in Sicily and Libya. We should be careful not to construct pasts that did not exist in our efforts to modernize our interpretations through a misconstrued sense of post-colonial theory that demands symmetry of power relations among all parties involved in colonial situations by considering the attested intercultural mobility of individuals as mirrors of large-scale intercultural alliances in establishing new foundations overseas.

Some other remarks should be made. Punic-period populations were selfidentified as Ponnim, ${ }^{6}$ which is omitted from the discussion on the supposedly only etic, extant ethnonyms of Phoenician/Punic groups (132, footnote 23). Dates of ca. $700 \mathrm{BC}$ for the emergence of states in Anatolia and the Greek world (p. 135) are too late. The settlement of the Phoenicians did not reach "from the Atlantic North-African coast to Algeria" (138) but to Libya (Lepcis). Several of the radiocarbon dates that appear in the discussion, most notably

6. C.R. Krahmalkov, A Phoenician-Punic Grammar (Atlanta: SBL Press, 2001). 
those of Carthage (141), were obtained from problematic samples and their use requires more caution. ${ }^{7}$

Importantly, in discussing pre-colonization, understood as a period where maritime connections paved the way to colonization, the authors refer to Tartessos as if it had been pre-existing. But in what sense? What was Tartessos that pre-existed the Phoenicians and what is the evidence for it? In the next section, the Late Bronze Age monumental "warrior stelae" of south-western Iberia are considered evidence for the "Tartessic society before the colonial wave" (159). By the end of this section, Tartessos turns up spatially in western Spain and southern Portugal at each place or region that eastern Mediterranean elements turn up as imports or influences in the material record of Iberia. But that is a methodologically problematic way of identifying a culture, society or civilization that anticipates the problems of Chapter 6.

Objects considered Mediterranean that are depicted in the "warrior stelae" of south-western Iberia have been for decades interpreted as the products of pre-colonial contacts. The problem is that these stelae pretty much lack contextual material, and as a result, their dating cannot be placed with certainty prior to the Phoenician colonization. The iconography of the stelae is reasonably related to finds from Ireland (V-notched shields, Atlantic swords), to the Aegean (Late Geometric vases from Greece) and to the Near East. Combs depicted on the warrior stelae are "unattested materially" (155) in precolonial Iberia. Yet ivory specimens are known from Phoenician/Orientalizing settlements (e.g. Carmona). So, does the depiction of Mediterranean objects on Iberian stelae predate the Mediterranean objects found in excavations? Depictions of V-notched shields on these stelae are compared to the wooden and leather V-notched shields found in Irish bogs and to the metal and clay miniature copies deposited in Greek sanctuaries in the Aegean in the $7^{\text {th }} \mathrm{c}$. BCE. Iberia is certainly the connecting link between the Irish and Greek artefacts, but the evidence here is used to consider "Tartessos part of the panHellenic cultic landscape" citing Pausanias' remark $\left(2^{\text {nd }} c . C E\right)$ that one of the treasuries at Olympia was made of Tartessic bronze (167). Does "multicultural" reflect the identities of people who visited Aegean sanctuaties or the origins of the votives consecrated to the temple? The horned, anthropomorphic figure depicted on the Magacela stela (Badajoz, Spain) is compared to a stela presenting a bull-headed bipedal in Beth Saida (Israel), implying crossMediterranean influences (p. 169). The suggested dates are close enough for iconographic influences as the authors imply. Another suggestion would be that emphasizing virility through the use of horns in a pre-historic, society where cattle played a vital role in sustenance is nothing uncommon. For example, schematic anthropomorphic sculpted figures bearing bull-horns are known in $2^{\text {nd }}$ millennium BCE Cyprus.

Wheeled, bronze stands with attached cauldrons from the settlement of Nossa Senhora da Guia - Baiões (Portugal) do not necessarily constitute precolonial local imitations of Cypriot designs as is suggested; rather, they could

7 E. Pappa, "Framing some aspects of the Early Iron Age 'chronological mess': Aegean synchronisms with the West and their significance for the Greek Geometric series," Kubaba 3 (2012): 2-38. 
be later hybrid forms of bronze tripods known from the Near East and Cyprus, and the Halstatt wheeled cauldrons knowns as Kesselwagen. ${ }^{8}$ Atlantic objects found in the eastern Mediterranean are few. On the Atlantic imports of Cyprus, referred to as "metallic grills and fibulae" (155), there is some confusion. The reference to "metallic grills" in particular is perplexing. If it refers to an Atlantic Iberian rotary spit (not grill) found in tomb 523 in Amathus (Cyprus), dated to ca. $1000 \mathrm{BCE},{ }^{9}$ then there is only one such other find in all of central and eastern Mediterranean, coming from the Monte Sa Idda hoard in Decimoputzu, Sardinia.

As to Cypriots importing Atlantic fibulae that later evolved into the known Phoenician types, the hypothesis is thoroughly unconvincing. These so-called Atlantic fibulae appear fully developed in Atlantic contexts of the early $1^{\text {st }}$ millennium BCE, yet their antecedents are known in the Near East. ${ }^{10}$ The roles of Cyprus and Sardinia in pre-colonial networks are rightly emphasized but here the postulation is that Mediterranean imports reached southern Spain through an overland, inland route southern from the Pyrennes (155). Maritime contacts between nuraghic Sardinia and Iberia ca. 1,000 BCE, independently of any eastern Mediterranean actors, are plausible, but do not necessitate inland routes.

Discussing the Ría de Huelva deposit, traditionally dated to the precolonial period, it is stated that the Phoenicians "did not establish a colonial enclave in Huelva" (171). In actuality, there is little information to suggest either way. The deposit from Huelva does not support the idea of Phoenician commerce in a native town. Rather, the recent finds of ca. $9^{\text {th }}$ BCE Phoenician workshops suggest otherwise. Despite the Phoenician-built ashlar wall in Huelva (San Pedro) and later sanctuaries known from the modern city, the authors claim that Phoenician activities betray a "mutual interest in exchanging raw material for novelty products and technologies" (171), but without a Phoenician residential establishment, in contrast to the Phoenician colonies located in the bays of Guadalquivir and Cadiz. In Malaga (La Rebanadilla), Middle Geometric Attic imports from Phoenician colonies belong to the same types as some of the earliest in Huelva ${ }^{11}$ that are considered pre-colonial. The archaeological record of Huelva is known from rescue excavations. Thus, its designation as an indigenous town a priory reifies the settlement as the heart of Tartessos, without adequate evidence.

Chapter 6 discusses settlement patterns and economic activities during the colonial period, with a valuable section on the sanctuary of Cancho Roano that has escaped attention outside Iberia. Here "changes in the territorial organization of Tartessos" are linked to Phoenician colonization and to "internal colonization of the hinterland" (175). There was little mention of territorial patterns in the previous chapter where Tartessos was traced to Huelva

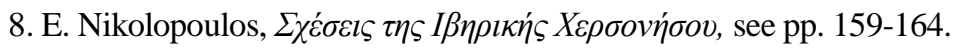

9. C. Vonhoff, "The Phenomenon of feasting in early Iron Age Cyprus. Bronze and Iron Obeloi from Cypriot Tombs as Evidence for Elite Self-Conception. Social Networks and Trans-Mediterranean Cultural Exchange", in Cahiers du Centre d'études Chypriotes 41 (2011): 133-152.

10. Nikolopoulos, $\Sigma \chi \varepsilon \dot{\sigma \varepsilon ı \iota \varsigma ~ \tau \eta ऽ ~ I ß \eta \rho ı и ́ \varsigma, ~} 19$.

11. Pappa, "Framing some aspects". 
and to the warrior stelae (e.g. Extremadura). The palaeogeomorphological transformations of the coastline of the provinces of Seville and Huelva resulted in several coastal regions now being inland (176-178), which raises questions as to this "internal colonization". A Tartessic colonization of Portuguese Atlantic regions has been previously postulated, ${ }^{12}$ but most Portuguese archaeologists would object to the idea of a Tartessic-style material culture on the Sado or the Tagus deltas deriving from a colonization wave. Castro Marim (Algarve) is referred to here as a colony when its excavator considers it an indigenous Orientalizing settlement, ${ }^{13}$ while even Alcácer do Sal (Alentejo), a settlement with pre-Bronze Age beginnings, is considered Tartessic in this chapter (180). The nomenclature derives from considering as Tartessic nonPhoenician material culture (and at times, Phoenician too), even when we know that there was ethnic, cultural and linguistic complexity of indigenous Iberian populations through to the Roman period. Without explanation, sites such as the sanctuaries of Carambolo (Seville), where the Near Eastern element is glaring, are called Tartessic too (178). This is not an argued identity but one that is simply ascribed to the sites by the authors. Although the authors admitted to limited knowledge on the political organization of the region (124), they bizarrely include Gadir, the Phoenician colony par excellence, into the "Tartessic territory" (175-176). So, in what way was Gadir Tartessic if it had been occupied by Phoenicians - a colony known to have maintained a strong Phoenician cultural identity until the Roman period? Is Tartessos conceptualized as a confederation of small states? The loose terminology results in methodological errors leading to an interpretational paradox.

Subsequently, economic activities, minining, agriculture and pastoralism are discussed, along with marine resources exploitation. It is unlikely that the mining industry was controlled by the local elites as claimed here (187). New mining techniques in Huelva correspond to the contexts of mixed indigenousPhoenician presence, but the onset of the Phoenician colonization furnished new mining techniques, as documented by archaeometallurgical research. ${ }^{14}$

The cultivation of domesticated species (vine, olive) in Iberia is overstated as to cultural interactions (193). For example, grafting trees is not the complex procedure it is made out to be. In the discussion of putative indigenous paticipation in the salted fish production of coastal Iberia, the argument is that it was Tartessic because the Phoenicians allegedly had no similar industries elsewhere (196). By contrast, a few pages later, the "salted fish" activities are considered a new, post $-6^{\text {th }}$ c. BCE Phoenician activity that affects Tartessos (204). In reality, across the southern Iberian coasts marine source cropping is well attested in the earliest levels of Phoenician colonies (e.g. Cerro del Villar, Toscanos in Malaga). However, there is limited archaeological evidence for fish-preservation activities in Iberia prior to the $6^{\text {th }}$ c. BCE. Sáez Romero

12. M. Torres Ortiz, "¿Una colonización tartésica en el interfluvio Tajo-Sado durante la Primera Edad?", Revista Portuguesa de Arqueología 8 (2005): 193-213.

13. M. Arruda, "A Idade do Ferro do Sul de Portugal. Estado da Investigacão", Madrider Mitteilungen 48 (2007): 114-139.

14. M.A. Hunt Ortiz, Prehistoric mining and metallurgy in Southern West Iberian Peninsula (British Aarchaeological Reports International Series 1188) (Oxford: Archaeopress, 2003). 
considers fishing to have been a specialized activity already in 800-600 BCE, tied to ship-building and pottery production, with exports to the indigenous hinterland. ${ }^{15}$ Exports of preserved fish in large storage vessels are documented at the indigenous settlement of Depreción de Ronda (Malaga), dated to the $7^{\text {th }} \mathrm{c}$. BCE. $^{16}$ The site may have had already Phoenician connections not limited to commercial exchanges. ${ }^{17}$ This evidence does not demonstrate that such activities were in the hands of Tartessians. Rather, it is the Phoenician colonies that seem active in the production of fish-related products. The later Greek sources referring to fish by-products, such as tarichos (derived from tuna and later sturgeon) mirror late archaic-classical export. ${ }^{18}$ All in all, there is simply no reason to argue for a Tartessic root in these activities, which start with the earliest occupation of Phoenician colonies. Fish-processing activities are archaeologically documented in the Punic period, from Portugal to Morocco, mainly after the declining of Tartessos, making the statement "it is difficult to calibrate the importance of salting during the floruit of Tartessos" (196) redundant.

The section entitled "the economy of an emerging state" (198-202) is perplexing, since there is no evidence for a Tartessic state, and the authors condemned in the introductory chapters the historiographical reification of Tartessos as a clear historical entity. Having dismissed past archaeological and historical research in the chase for a mythical Tartessos in the opening book chapters, here the authors create another historical construct, by referring to Tartessos as a "state" no less. This is not borne by any archaeological reality whatsoever. This ensuing discussion exhausts itself to describing exchange in luxury goods, issues of conflict, Phoenician cults (with no reference to temple economy whatsoever), and urban infrastructure but leaves out any reconstructions of commercial patterns in bulk, of which there is ample information, commercial structures, trade networks, the possible currencies used and questions on power relations.

The following section (202-213) discusses the causes of the $6^{\text {th }} \mathrm{c}$. BCE crisis of Tartessos. The subjugation of Tyre in the early $6^{\text {th }}$ c. BCE is discounted, but the Battle of Alalia in Corsica between Greeks and an alliance of Etruscans and Carthaginians (540 BCE), as reported by Herodotus, is considered a "turning point" (203) that led to a reconfiguration of Greek and Carthaginian commercial circuits. Another possibility is a natural cataclysmic disaster, suppodely seen in geological cores from the Guadalquivir

15. A.M. Sáez Romero, "Fish processing and salted-fish trade in the Punic West: new archaeological data and historical evolution", in Fish and Ships: Production et Commerce des Salsamenta durant l'Antiquité, Actes de l'atelier doctoral (Rome 18-22 juin 2012), ed. E. Botte and V. Leitch, Bibliothèque d'Archéologie Méditerranéenne et Africaine 17 (Paris: Centre Camille Jullian, 2014), 159-174.

16. Sáez Romero, "Fish processing", see p. 163.

17. P. Aguayo, M. Carrilero and G. Martínez, "La presencia fenicia y el proceso de aculturación de las comunidades del Bronce Final dela Depresión de Ronda (Málaga)", in Atti del II Congresso Internazionale di Studi Fenici e Punici, (Roma, 9-14 novembre 1987), vol. 2, ed. E. Acquaro, P. Bartoloni, M. T. Francisi, L. I. Mazza, G. Montalto, G. Petruccioli, S. Ribichini, S. Scandone and P. Xella, Collezione di Studi Finici 30, (Roma: Consiglio Nazionale delle Ricerche, Istituto per la civiltà fenicia e punica, 1991), 559-571.

18. E.g. Sáez Romero, "Fish processing", see p. 160. 
palaeoestuary (Huelva) dated to "some time in the $6^{\text {th }}$ century" (206). The geological study ${ }^{19}$ referenced by the authors, however, cites a potential tsunami or storm event whose calibrated dates at the latest dates to the Middle Bronze Age (ca. 1300 BCE) and cannot explain a crisis 700 years later.

While exogenous factors should not be the only point of reference, the authors could have taken into account the wider historical circumstances. The widespread abandoment of coastal Phoenician settlements in southern Iberia coincides with loss of independence for Phoenician cities in Lebanon. Tyre remained in siege for 13 years at the end of the $6^{\text {th }} \mathrm{c}$. BCE and was subsequently annexed by Babylonia. Recent translations of Babylonian clay tablet texts show that Tyre was occupied by Babylonian troops that build their garrison on the island, while the Tyrian royal house was forced to exile in Babylonia. By the time Tyrian monarchy was reinstiuted, each monarch was sent to Tyre from Babylonia when the throne was vacated. ${ }^{20}$ The political and economic collapse of Tyre as an autonomous power had conceivably repercussions in its Mediterranean foundations, generating a cascade of economic effects that must have disrupted pre-existing economic synergies and contributed to the abandoment of commercially-oriented Tyrian foundations in southern Spain.

Chapter 7 concerns religion and cult life. After a discussion of Phoenician religion, sanctuaries and other evidence pertaining to "Tartessic cult life" are discussed. The sanctuaries of Carambolo and Cancho Roano are described in more detail. Even the earliest of the two, Carambolo, is considered "indigenized", despite acknowledging that little is known of pre-Phoenician ritual customs (232). One wonders reading this chapter if the indigenous "oval huts of the Bronze Age" at Cancho Roano (245) will turn out to be the bothros of a Near Eastern-style sanctuary, as happened recently with the famous indigenous hut of the Carambolo sanctuary. The Phoenician temple of Melqart in Gadir is presented as the "most famous" temple to Melqart in the western Mediterranean (233), yet all the while Gadir appears as located in Tartessic territory. The sanctuaries discussed are interpreted with recourse to Phoenician and Egyptian religion, but they are called Tartessic sanctuaries. If this is to show a new local religion or cult, this remains unexplored. Further, comparisons of the oxhide-shaped altar of Cancho Roano B with cultic features in Cyprus are chronologically muddled. There is a reference to the "horn of consecration" in Kition (modern Larnaca). The latter, however, pertains to Temple 1 (Area II) that yielded LH IIIC pottery prior to the destruction level, thus predating any Phoenician involvement in Kition. The oxhide form is known from Late Bronze Age Enkomi as a weight or miniature votive. An alternative possibility is that its form spread from the Hittite world, where the

19. A. Rodríguez-Ramírez et al. "Atlantic Extreme Wave events during the last four millennia in the Guadalquivir estuary", Quaternary Research 83, no. 1 (2015): 24-4.

20. C. van der Brugge, C. and K. Kleber, "The empire of Trade and the empires of force. Tyre in the Neo-Assyrian and Neo-Babylonian periods", in Dynamics of Production in the Ancient Near East, 1300-500 BC, ed. J. Moreno Garcia, Dynamics of Production in the Ancient Near East, 1300-500 BC (Oxford: Oxbow Books), 187-222. 
shape denoted the hieroglyph for "earth", and was associated iconographically with gods standing on them. ${ }^{21}$

Subsequently, the heterogeneity of funerary customs at necropoleis in southern Iberia is discussed. Funerary rites are not passed on with the easiness of acquiring exotic goods, as religious beliefs come into play; thus the designation of them as Tartessic needs explanation. The adoption of Phoenician funerary customs (cremation) needs scrutiny if we are not dealing with communities of Phoenician descent. After all, many of the funerary customs of necropoleis such as the Cruz del Negro (Carmona, Seville) have close affinities with Phoenician necropoleis in Lebanon, as confirmed by the excavations directed by M. E. Aubet in the contemporary Tyrian necropolis of Al-Bass. ${ }^{22}$ Cruz del Negro urns, named after an inadequately published necropolis in Carmona (261) are not some locally imaginative creation as it is implied ("an emblematic signpost of Tartessic culture"), but derive from the Near Eastern Cypriot Bichrome Ware, consisting in a wide variety of ceramic types decorated with parallel red bands and black lines. While the decoration is known as "polychrome" or "painted" in Iberian archaeology and the urns of this style as Cruz del Negro in the attempt to "indigenize" their origins, this dictinctive decoration appears as early as the Middle Bronze Age II in Palestine. In the Iron Age, it is found in Phoenician colonies in north Africa and elsewhere. ${ }^{23}$

Chapter 8 discusses art and the technology: ceramics, metalwork, ivories and peculiarly, script and writing. The authors postulate a "Mediterranean inflection" on the Carambolo ware (271). The influence of Greek Geometric pottery on the decoration of these ceramics is not unanimously accepted in Iberia. Its decoration may have been influenced by Greek Geometric pottery, as such imported vases are known from Malaga and in Huelva, which makes the transmission of influences conceivable. The Orientalizing ware of the "Carmona style" features naturalistic griffins and lotus flower motifs. The lotus flowers are a recurrent motif on pottery from $2^{\text {nd }}$ millenium BCE Cyprus, and from Phoenicia, originating in Egypt where the flower was associated with a safe transition to afterlife. Questions such as whether the Carmona finds show

21. E. Pappa, "Oriental gods but domestic elites? Religious symbolism and economic functions of Phoenician-period cult loci in southern Iberia", in Sanctuaries and the Power of Consumption. Networking and the formation of Elites in the Archaic Western Mediterranean World, Proceedings of the International Conference in Innsbruck, 20th-23rd March 2012, ed. E. Kistler, B. Öhlinger, M. Mohr and M. Hoernes,PhilippikaAltertumswissenschaftliche Abhandlungen/ Contributions to the Study of Ancient World Cultures 92 (Wiesbaden: Harrassowitz Verlag), 43-62, see p. 49-50.

22. From the publication output of the exacavations, see indicatively e.g. M. E. Aubet, "Cremation and social memory in Iron Age Phoenicia", in Ritual, Religion and Reason. Studies in the Ancient World in Honour of Paolo Xella, ed. O. Loretz, S. Ribichini, W.G.E. Watson, J.Á., Zamora, Alter Orient und Altes Testament 404 (Münster: Ugarit-Verlag), 7787.

23. R. Docter, "Bichrome Ware Amphorae from Al Mina, Kition and Carthage", in Ritual, Religion and Reason. Studies in the Ancient World in Honour of Paolo Xella, ed. O. Loretz, S. Ribichini, W.G.E. Watson, J.Á., Zamora, Alter Orient und Altes Testament 404, (Münster: Ugarit-Verlag), 89-102. 
the transmission of iconographic motifs or that of religious ideas are not addressed.

It is buffling why a section on language and writing, curcial indicators of identity, are buried in the last section of the last chapter. Epigraphic and linguistic evidence can furnish invaluable information on cultural identity, as well as political formation, which the authors try to address in this volume. Yet here, this evidence remains unexploited. Had this discussion on language and script be included earlier in the book, it would have demonstrated the methodological futility of reading a "Tartessic" identity everywhere in the archaeological record of a region that stretches from Cádiz (Huelva) to Badajoz (Extremadura) to Lisbon (Portugal). Instead, the disparity of linguistic groups would have to be acknowledged and correlated with other insignia of identity and social organization. Later, coinage could have been used too, seeing as the disparate metrical systems and scripts represented in the early minted coins at the time of Roman conquest belie cultural and political groups of centuries earlier. All these sets of evidence undercut the suggestions of Tartessos as an"emerging state". Indigenous and Phoenician populations in south-western Iberia were not homogeneous groups, the former much more than the latter.

The book's Epilogue ends with some open questions, further stretching the loose semantics of the monograph, concluding that "we can talk about 'Tartessians' as the communities who inhabited this territory independently of their ethnicity, culture and status" (302) and later on, "so we might extend the Tartessic label to the indigenous culture with which later Mediterranean peoples made contact in the tenth-ninth centuries" (302). Reduced to a catch-all phrase, Tartessos is then empty of meaning, redundant as an archaeological term (for Tartessic can refer to pre-colonial as well as to colonial-period material culture) and certainly also redundant as a historical designation of a culture (for the authors claim it was not a culture). These two paragraphs encapsulate the conceptual confusion of what in reality forms the archaeological remains of a socially, politically, culturally and ethinically diverse proto-historical period in Iberia. The main question of whether Tartessos existed as a self-recognized entity in the proto-historical period of Iberia remains answered, at the same time as Tartessos has been construed with no corroborating evidence as a state.

\section{So, What is Tartessic and Who Was a Tartessian?}

The book is permeated by conceptual pitfalls that are castigated in the opening sections of the book itself: reifying past historical realities through repetition of factoids in the literature that turns into a historiographical tradition. Though hedging from place to place, the authors view Tartessos in a muddled way, as an indigenous culture, a hybrid culture (but we are told throughout, it was not a culture) and as an indigenous state with some Orientals (including famous Phoenician colonies, such as Gadir). Cultural contact fluidity cannot account for the semantic mix-up of this sort. The wisdom of the words found in Chapter 1 on deconstructing the historiographical creation of Tartessos did not 
affect the analysis in the rest of the book, where Tartessos shifts from appearing as a staunchly indigenous, pre-colonial entity to being a "state" to emerging in the book's conclusion as a catch-all term linked to a vague territory in southwestern Iberia with no reference to a specific culture, ethnicity or social formation from ca. 1,100 to 500 BCE. By the Epilogue of the monograph, Tartessos is no longer an archaeological culture in the sense of a material record of finds sharing common characteristics, neither a past social culture, a state or a region, but its study has become "a discipline in itself" (308). Despite reflecting on Mediterranean networks in the book, Tartessos here is not really seen as part of the proto-history of southern Iberia, transformed by Phoenician colonization and intimately linked to the eastern Mediterranean. Rather, it has transcended pesky philological, historical and archaeological dichotomies to the point of becoming a discipline to itself.

This forms a main conceptual error of how to approach Tartessos, which reflects the errors of past decades of research (despite the opening theoretical excursus on post-colonial theory). Such errors also explain why Tartessos is not well-known outside Iberia (as stated in the Preface), since in effect it is approached as an entity of its own, even as no logically consistent definition exists for it. Once the literary and archaeological evidence comes into the discussion, Tartessos is treated as a territory, albeit one whose geographical borders are shifting each time some spectacular site is unearthed. From Huelva and Seville, to Algarve and Extremadura, Tartessos' territorty shifts to encompass "warrior stelae" or other monumental finds. This conceptual error results in semantic and historical paradoxa, as when Gadir, the famous Phoenician colony par excellence is considered to be in Tartessic territory (and state) - yet the Phoenician foundations on the Mediterranean coast of Spain, much smaller, are left out. Is the implication here that these small Phoenician settlements, such as Morro de Mezquitilla were independent, but Gadir was not? The Near Eastern-style sanctuary at Carambolo is treated as founded in Tartessic sanctuary, without being Phoenician. Yet all the interpretations of it are based on Phoenician culture and civilization. What makes it a Tartessic sanctuary then? The religious rites, the architecture, the finds? The pilgrims that frequented it? Its physical location in Iberia, pure and simple? Does Tartessos include all sites in southern-central Portugal or only those with "Tartessic" pottery? Can sites in Extremadura with no evidence for an Orientalizing horizon be considered Tartessic? Did the people living in south-western Iberia self-identify as Tartessians (whether by a cognate ethnonym or not)? Is Tartessos a valid category by which to analyze social identity and sociopolitical formation (the authors' "emerging state" of Tartessos?).

It seems to me that the answer is no. To keep the term Tartessos as archaeologically valid so as to denote the Orientalizing style of southern Iberia or the period corresponding to it is a persuasive suggestion, to turn it into a culture, a state or a disciplinary field, not so. The semantics in flux permeating the monograph begs the question of why a book on something as loosely defined as Tartessos is needed in the first place. Why not study the early $1^{\text {st }}$ millennium BCE across southern Iberia for example, if no ethnic, cultural, social or chronological cohesion can be said to permeate Tartessos, as it 
appears in the book's conclusions? While the authors acknowledge the pluralism of languages spoken in Iberia, they completely ignore this fact of linguistic fragmentation in their demarcation of the boundaries of ethniccultural identities of Tartessos that shrinks and expands opportunistically according to spectacular archaeological finds, charting its territory where monumental finds and Mediterranean material culture have come to light. What if the archaeological evidence were to be correlated with linguistic patterns? What would the emerging picture be then? The fact that neither of the authors is a specialist in this area of research (epigraphy or linguistics) would not prevent them from accessing recent bibliography. Latest research points to the fact that a non-Indo-European language was spoken in the southern-east of the Peninsula (the core of Phoenician ports of trade in Malaga and Granada), while an Indo-European language was spoken in the area where the South-West inscriptions are found (western Andalusia and southern-central Portugal). The South-West script was adapted from the Phoenician one. There is no consensus on the language that belies this new script, but the distribution patterns of inscribed stelae cluster more densely in Portuguese territory, forming the western periphery of the Phoenician/Orientalizing (archaeological) horizon of the Guadalquivir valley. Thus, the South-West script and the underlying language was spoken west of the Tartessic culture, and perhaps formed a territory that was geographically and culturally peripheral to it - if such a culture ever existed as a socio-cultural formation and not merely as an archaeologically visible commonality in material culture spreading with the diffusion of Phoenician culture in the region. The contested readings of the South-West corpus of inscriptions include the model of a Celtic-speaking society with a low socio-political organization. ${ }^{24}$

Thus, how can we talk of Tartessic identity when this putative identity follows the trajectory of spectacular archaeological finds, and recognizable artefacts, but ignores differential settlement patterns and the linguistic fragmentation of the populations that made it up? Settlements patterns and the consumption of goods, as well as production, burial customs and other indicators of identity could tell us something in terms of identity, but not selectively. The conglomerate of finds discussed does not pinpoint to a singular society turned state, and if one takes into account the linguistic evidence, it precludes linguistic uniformity and supports the model of a culturally, ethnically and politically fragmented landscape of low-level social organization. It is precisely this low hierarchical formation that would have permitted the Phoenician expansion. Military conflict instigated by armies hailing from the other end of the Mediterranean is a highly unrealistic scenario. At most, what we see is a conglomerate of tribal-level indigenous societies, some influenced materially more than others from the Phoenician colonies in Iberia. The former would have been economically depended, to some degree, on Tyrian colonies founded on the shores of a sparsely inhabited southern Iberia. The degree of political interdependence of the colonies must remain open to discussion. The most valid hypothesis of a polity pre-existing

24. J.T. Koch, Tartessian. Celtic in the South-West at the Dawn of History, Celtic Studies Publications XIII (Aberystwyth: The David Brown Book Co, 2009). 
Phoenician colonization would rely on the identification of Tarshish with Tartessos, as suggested by the authors. However, such identification does not confirm the presence of a local polity, much less a "proto-state". It could have referred to a toponym, known from maritime connections. Herodotus' historical understanding of Tartessos as a kingdom may have reached the Greeks through sailors' hearsay of Iberian societies, inflated by cultural suppositions based on Greek understanding of state formation and separated by some centuries.

In this monograph, the historical/archaeological reification of Tartessos is married to a "post-colonial" fetishistic approach to deconstructing historically documented cultures. While boldly assuming the existence of a Tartessic identity and drawing associations between ancient baalic - bull symbols in Iberia with matadores in modern Spain ("who can resist alluding to the importance of bull culture in Spanish culture to this day, with other connotations and expressions?", on p. 240), the authors eradicate documented historical Mediterranean cultures and ethnicities tout court on the altar of a misconstrued sense of post-colonialism. Post-colonialism was meant to provide a voice to cultures and nations eliminated by a western sense of superiority, but it has now moved to eradicating past cultures too - in an equally misguided sense of an intellectually superior or vantage point. Presumably so as to avoid repeating the mistakes of the past in the history of archaeology (on notions of civilizing barbarians that were used to legitimize European empires), the word Greeks in the monograph is put, for example, into scare quotes: "Let us not lose sight of the fact that all cultural and ethnic categories are constructed by a process, external and internal, that involves abstraction, reification, and generalization; take 'the Greeks', themselves, 'the West', 'Europe', and so many others" (124). The Greeks, who have a continuous linguistic (at least, but also cultural) presence of over 3000 years in the same territory and plenty of emic sources spanning thousands of years to document their existence, have to be referred to with scare quotes as their identity allegedly "involves abstraction, reification, and generalization" (124). Yet Tartessic identity, which the authors explicitly acknowledged as difficult to pin down for lack of any emic sources, emerges in this book first as staunchly indigenous and then a historically real, local identity in southern Iberia, whose insignia appear in modern bull-fighting in Spain.

Trite platitudes with a wink to the (abused) post-colonial concepts are referenced to demarcate a (not ethnic and not cultural, as we are told...) Tartessic identity based on few external, fragmentary sources dating to centuries later. This conceptual flattening of the evidence may be the sort of thing that superficially satisfies trends within the liberal arts academy in its effort to align with post-colonialism, but as previously noted, ${ }^{25}$ any such account becomes extremely tedious and uninformative in the end when stretched to this extent. The surprising take in this post-colonial version is that the flattening of historically documented identities happens in the effort to define a brand new, specifically southern Iberian ancient identity - Tartessic -

25. A. Kaldellis, Hellenism in Byzantium. The Transformations Of Greeks, Identity and the Reception of the Classical Tradition (Cambridge: Cambridge University Press, 2008). 
which on the basis of completely absent emic sources must remain extremely tentative at best.

To sum up, the greatest value of this book lies in the discussion of etic literary texts of the Greco-Roman period connected to Tartessos and related ethnonyms, as well as the presentation of newly excavated sites (e.g. Carambolo, Cancho Roano, La Angorilla). Its interpretations and general framework of understanding the evidence should be read with caution, however.

\section{Methodological and Conceptual Problems in Studying Iberian Proto- History: A Way Forward}

The volume reviewed here illustrates the methodological and interpretational pitfalls that have pervaded the archaeology of this period in southern Iberia that affects the understanding of Tartessos. ${ }^{26}$ Several derive from conceptual rigidity. This is seen, for example, in the use of pottery for dating sites. Once a pottery style known from the eastern Mediterranean is considered Tartessic, the potential it has to illuminate the cultural aspects of a site or aid towards it dating is greatly diminished because $a$ priori it is seen as a local, Iberian development.

Chronology in Iberia in the period dealing from the $12^{\text {th }}$ century to the $5^{\text {th }}$ c. BCE is a major issue. Ceramic styles attributed to the Final Bronze Age period of Iberia (e.g. reticula bruñida, pottery with finger impressions on the shoulders) continue more or less unchanged for centuries in large territories. Their production must have been widespread but decentralized, in dispersed, small workshops or perhaps in domestic contexts. At any rate, the nonstandardized nature of these pottery styles makes it difficult to devise precise typologies, since the same decoration appearing in different types of bowls, jugs and storage vessels (made from coils or on the slow wheel) shows little variation. A typological system that would use this style from across Iberia to chart chronological differences has not been attempted, but it is unlikely that such variation would be useful in dating sites even to a specific century.

These pottery styles, attributed by convention to the Final Bronze Age traditions of Iberia, overlap chronologically with the Early Iron Age in the Mediterranean, and thus with imports arriving from Phoenicia, Greece and elsewhere, as well as the local imitations the latter spurned. Since the production of these indigenous styles continues for centuries, they cannot lend themselves to dating accurrately sites the way contemporary Phoenician or Greek pottery permits with the accuracy of often a decade's margin. In that sense, taking a style of pottery as significant, and forgetting the relative stylistic chronology (Bronze Age for indigenous styles, Iron Age for imports), we

26. See a thorough treatment of these problems in: E. Ferrer Albelda, "La colonización en la Tartéside estrategias e fases", in Territorios Comparados: Los valles del Guadalquivir, el Guadiana y el Tajo en Época Tartésica, ed. Celestino Pérez, S. and E. Rodríguez González, Anejos de Archivo Español de Arqueologia LXXX (Mérida: Consejo Superior de Investigaciones Científicas, 2017), 11-46. 
construct an artificial historical reality, where every handmade pot denotes some kind of pre-existing native horizon of the Bronze Age (i.e. of the $2^{\text {nd }}$ millennium BCE down to the $8^{\text {th }} \mathrm{c}$. BCE) unless found in association with imports. In reality, such handmade pottery may pertain to an archaeological context of ca. 650 or 550 BCE known from rescue excavations, which if extended spatially to larger surfaces could show a settlement with Phoenician or Orientalizing pottery of different dates. A need for context would require us to update our information on chronology every time a site published in earlier decades as Bronze Age or Iron Age is cited presently. In parallel, radiocarbon dating needs to be used with more prudence, discussing the quality of each sample used, and citing returned dates at both 1 and 2 sigma. $^{27}$

Another problem is that sites get excavated often in the course of rescue excavations, remain unpublished as scientific reports submitted to authorities, or they lend themselves to becoming the subject of student dissertations (the latter in Portugal). Thus, the excavations themselves are often unaccessible to the broader scholarly community for cross-referencing data and chronological comparanda from elsewhere in the Mediterrarnean.

Scientific contributions to Iberian archaeology (both in Spain and Portugal) have enjoyed an exceptional surge in the past twenty years (archaeometallurgy, palaeomagnetic dating, radiocarbon, isotopic and other chemical analyses). The results of these studies, however perfect the actual scientific method followed, have per force diminished potential when the samples are selected out of unpublished excavation contexts whose description is not available, cannot be accessed, or cross-referenced. Their value, other than having a nebulous general view of an unknown ceramic repertoire sample's chemical composition, from an unpublished site and thus unknownable context, lies either in testing the capabilities and limits of the scientific method per se, or in accumulating data that might come of use in the future, if and when these sites do get published or for broad comparisons with future studies on same classes of material. This is not the most fruitful avenue of investigation, if results are to be useful in the present. Since such scientific programmes do take place, the best avenue would be for samples to come from sites with detailed published contexts, rather than selecting specimens from unpublished contexts so that something is "done about them" in the sense of having a publication appearing from $\mathrm{X}$ rescue excavation. The results of a perfect archaeometric analysis, for example, cannot be used in a meaningful way archaeologically unless they come from published contexts with published contextual assemblages. Tables upon tables of data measurements do not furnish the value they could provide unless the questions asked about them can be answered on the basis of context.

To avoid also an inward look that does not lend itself to self-referential understandings of colonial grounds, where some elements were indeed external, a pan-Mediterranean view has to be adopted. That Phoenician settlements in southern Spain show widespread abandonment in the early $6^{\text {th }}$ century BCE, when in the eastern Mediterranean Tyre falls into the Babylonians, demonstrates the vital, political and economic links of Phoenician colonies with Tyre. Beginning with what evidence does exist and then moving

27. Pappa, "Framing some aspects". 
on to hypotheses is more productive than favouring speculations on environmental catastrophes, which untie the proto-history of a colonized region from its historical, political, economic and social context in the Mediterranean.

A symptom of a wider problem of a priori interpretations selectively using archaeological data in order to materially document pre-conceived notions is reflected in designations of sites as "indigenous" or not on scarce evidence. This reiteration over the years and decades in the scholarly output creates factoids, in the sense that they have become an over-repeated storyline. On present knowledge, there existed maritime connections between Huelva and north Atlantic regions, as well as with the Mediterranean by the turn of the $2^{\text {nd }}$ millennium BCE, after which point architectural and other evidence shows an intense settlement of people from the eastern Mediterranean, incuding workshops and sanctuaries. The exact nature of the settlement, its demographic make-up and its political organization will have to await future research. Finally, an issue of proto-historical archaeology that needs to be taken seriously is the diffused, faux gendered archaeological interpretations, which result in direct equations of hand-made Iberian-typology pots with "indigenous (Iberian) wives". For by that kind of logic, given the presence of Final Bronze Age pottery types in northern Africa, indigenous Iberian wives should be seen in Lixus, in Carthage and elsewhere where this pottery turns up with Phoenicianstyle imports. Is this the best we can do?

\section{Acknowledgment}

The research for this article was carried out during two linked postdoctoral research projects $(2015 / 26909-0 ; 2018 / 01268)$ funded by the São Paulo Research Foundation (Fundação de Amparo à Pesquisa do Estado de São Paulo - FAPESP) and hosted by the Laboratory for the Studies of the Ancient City (Laboratório de Estudos sobre a Cidade Antiga - LABECA) at the Museum of Archaeology and Ethnology (Museu de Arqueologiua e Etnologia) of the University of São Paulo and by the Department of Prehistory and Archaeology (Departamento de Prehistória y Arqueología) of the University of Seville, respectively.

\section{Bibliography}

Aguayo, P., Carrilero, M., and G. Martínez. "La Presencia Fenicia y el proceso de Aculturación de las Comunidades del Bronce Final dela Depresión de Ronda (Málaga)." In Atti del II Congresso Internazionale di Studi Fenici e Punici, (Roma, 9-14 novembre 1987), vol. 2, edited by E. Acquaro, P. Bartoloni, M. T. Francisi, L. I. Mazza, G. Montalto, G. Petruccioli, S. Ribichini, S. Scandone and P. Xella, Collezione di Studi Finici 30. Roma: Consiglio Nazionale delle Ricerche, Istituto per la civiltà fenicia e punica, 1991.

Arruda, M. "A Idade do Ferro do Sul de Portugal. Estado da Investigacão". Madrider Mitteilungen, no. 48 (2007): 114-139. 
Aubet, M.E. "Cremation and Social Memory in Iron Age Phoenicia." In Ritual, Religion and Reason. Studies in the Ancient World in Honour of Paolo Xella, edited by O. Loretz, S. Ribichini, W.G.E. Watson, J.Á., Zamora, Alter Orient und Altes Testament 404, 77-87. Münster: Ugarit-Verlag.

Celestino Pérez, S. and E. Rodríguez González. (eds.) Territorios Comparados: Los valles del Guadalquivir, el Guadiana y el Tajo en Época Tartésica. Anejos de Archivo Español de Arqueologia LXXX. Mérida: Consejo Superior de Investigaciones Científicas, 2017.

Docter, R. "Bichrome Ware Amphorae from Al Mina, Kition and Carthage". In Ritual, Religion and Reason. Studies in the Ancient World in Honour of Paolo Xella, edited by O. Loretz, S. Ribichini, W.G.E. Watson, J.Á., Zamora, Alter Orient und Altes Testament 404, 89-102. Münster: Ugarit-Verlag.

Ferrer Albelda, E. "La colonización en la Tartéside estrategias e fases". In Territorios Comparados: Los valles del Guadalquivir, el Guadiana y el Tajo en Época Tartésica, edited by Celestino Pérez, S. and E. Rodríguez González, Anejos de Archivo Español de Arqueologia LXXX. Mérida: Consejo Superior de Investigaciones Científicas, 2017.

Harrison, R. Spain at the Dawn of History: Iberians, Phoenicians and Greeks. London: Thames and Hudson, 1988.

Hunt Ortiz, M.A. Prehistoric mining and metallurgy in Southern West Iberian Peninsula, British Aarchaeological Reports International Series 1188. Oxford: Archaeopress, 2003.

Kaldellis, A. Hellenism in Byzantium. The Transformations Of Greeks, Identity and the Reception of the Classical Tradition. Cambridge: Cambridge University Press, 2008.

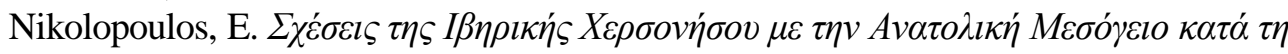

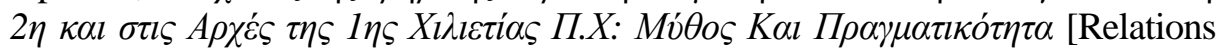
between the Iberian Peninsula and the Eastern Mediterranean in the 2nd and the beginning of 1st millennium BC: Myth and Reality], Ph.D. Diss., National and Kapodistrian University of Athens, 2009.

Krahmalkov, C.R. A Phoenician-Punic Grammar. Atlanta: SBL Press, 2001.

Koch, J.T. Tartessian. Celtic in the South-West at the Dawn of History, Celtic Studies Publications XIII. Aberystwyth: The David Brown Book Co, 2009.

Pappa, E. "Framing some aspects of the Early Iron Age 'chronological mess': Aegean synchronisms with the West and their significance for the Greek Geometric series". Kubaba 3 (2012): 2-38.

Pappa, E. "Oriental gods but domestic elites? Religious symbolism and economic functions of Phoenician-period cult loci in southern Iberia". In Sanctuaries and the Power of Consumption. Networking and the formation of Elites in the Archaic Western Mediterranean World, Proceedings of the International Conference in Innsbruck, $20^{\text {th }}-23^{\text {rd }}$ March 2012, edited by E. Kistler, B. Öhlinger, M. Mohr and M. Hoernes,Philippika-Altertumswissenschaftliche Abhandlungen/ Contributions to the Study of Ancient World Cultures 92. Wiesbaden: Harrassowitz Verlag.

Rodríguez-Ramírez, A. et al. "Atlantic Extreme Wave events during the last four millennia in the Guadalquivir estuary". Quaternary Research 83,1 (2015): 24-4.

Sáez Romero, A.M. "Fish Processing and Salted-Fish trade in the Punic West: New Archaeological Data and Historical Evolution". In Fish and Ships: Production et Commerce des Salsamenta durant l'Antiquité, Actes de l'atelier doctoral (Rome 18-22 juin 2012), edited by $E$. Botte and V. Leitch, Bibliothèque d'Archéologie Méditerranéenne et Africaine 17. Paris: Centre Camille Jullian, 2014, 159-174. 
Torres Ortiz, M. "¿Una colonización tartésica en el interfluvio Tajo-Sado durante la Primera Edad?" Revista Portuguesa de Arqueología 8 (2005): 193-213.

van der Brugge, C. and Kleber, K. "The empire of Trade and the empires of force. Tyre in the Neo-Assyrian and Neo-Babylonian periods". In Dynamics of Production in the Ancient Near East, 1300-500 BC, edited by J. Moreno Garcia, Dynamics of Production in the Ancient Near East, 1300-500 BC., 187222 Oxford: Oxbow Books.

Vonhoff, C. "The Phenomenon of feasting in early Iron Age Cyprus. Bronze and Iron Obeloi from Cypriot Tombs as Evidence for Elite Self-Conception. Social Networks and Trans-Mediterranean Cultural Exchange". Cahiers $d u$ Centre d'études Chypriotes 41 (2011): 133-152. 
